\title{
POLITIK IDENTITAS ERA ORDE BARU DI INDONESIA MEMASUKI ERA REFORMASI
}

\author{
John Musa Renhoard \\ Asisten Dosen STT Cipanas
}

\begin{abstract}
This article entitled "Identity Politics of New Order Era in Indonesia Entering Reformation Era" discusses the development of relations between Christians and Muslims due to political policies during New Order government which had an impact after the government was ended. In this paper, it is first presented an outline of the history of New Order government and then continued with a discussion of religious political policies during the administration. The discussions were directed at several events that took place at the beginning of the Reformation era and finally the impact of identity politics carried out by the government. In this paper it was found that although each major event that took place in this nation did not have a relationship with the two religions at that time, but with religious nuances at the end of New Order government between the two religions namely Christianity and Islam in some regions, identity politics happened in the government.
\end{abstract}

KEYWORDS: New Order, Christianity, Islam, reform.

ABSTRAK: Artikel yang berjudul "Politik Identitas Era Orde Baru di Indonesia Memasuki Era Reformasi" membahas mengenai perkembangan relasi di antara umat Kristen dan Islam akibat kebijakankebijakan politik di masa pemerintahan Orde Baru yang berdampak setelah pemerintahan tersebut berakhir. Dalam tulisan ini, pertama disajikan garis besar sejarah pemerintahan Orde Baru dan kemudian dilanjutkan dengan pembahasan mengenai kebijakan politik agama pada masa pemerintahan tersebut. Pembahasan fokus pada beberapa peristiwa yang terjadi di awal era Refomasi serta dampak politik identitas yang dilakukan oleh pemerintahan tersebut. Dalam tulisan ini ditemukan 
bahwa walaupun setiap peristiwa-peristiwa besar yang terjadi di bangsa ini tidak memiliki hubungan dengan kedua agama pada masa itu, namun dengan adanya konflik bernuansa agama di akhir pemerintahan Orde Baru di antara dua agama yaitu Kristen dan Islam di beberapa daerah menunjukkan bahwa terdapat relasi terjadinya politik identitas pada awal Reformasi dengan politik identitas yang dimainkan pemerintahan Orde Baru.

KATA-KATA KUNCI: Orde Baru, Kristen, Islam, reformasi

\section{Pendahuluan}

Konflik bernuansa suku, agama, ras dan antargolongan (SARA) yang terjadi di Indonesia menjelang berakhirnya pemerintahan Orde Baru bukan hanya menimbulkan korban nyawa dan harta benda, tetapi juga berdampak panjang dalam hubungan antarkelompok masyarakat di Indonesia sampai pada Era Reformasi, secara khusus dalam hubungan Kristen dan Islam. Politik identitas yang dimainkan rezim Orde Baru secara khusus menjelang kejatuhannya menjadi lembaran kelam politik identitas di Indonesia yang dampaknya berlanjut di Era Reformasi. Bahkan, hubungan antaragama di Indonesia yang dulu terjalin harmonis, kini pada tempat-tempat tertentu terbentuk cluster-cluster agama. Kondisi tersebut menyebabkan kecurigaan antarpemeluk agama semakin menguat. Maka tidak lagi mengherankan jika hanya karena persoalan kecil dapat meledak konflik yang berujung pada aksi kekerasan. Apalagi di era teknologi informasi seperti saat ini, media sosial (medsos) yang sering menyebarkan aneka informasi yang sifatnya provokatif dan tanpa kendali, membuat kondisi hubungan antarmasyarakat yang peka itu kerap menyulut konflik bernuansa SARA.

Melihat maraknya konflik antarkelompok menjelang kejatuhan Orde Baru yang terus berlanjut di awal Reformasi, timbul pertanyaan, bagaimanakah politik identitas yang dimainkan Orde Baru? Apakah konflik agama di akhir era Orde Baru itu dipengaruhi politik identitas? Bagaimanakah kondisi hubungan antaragama di awal Era Reformasi? 
Apakah konflik agama di akhir Orde Baru itu memengaruhi hubungan antarkelompok masyarakat di Indonesia pada awal Reformasi? Tulisan ini akan menjawab pertanyaan-pertanyaan itu.

Penelitian ini dibangun berlandaskan pada paradigma deduktif, dari hal umum berupa generalisasi teori politik identitas era Orde Baru kepada hal-hal khusus terkait konflik agama di akhir Orde Baru dan di awal Reformasi. Pertama-tama dibangun sebuah konstruksi mengenai politik identitas Orde Baru sebagai hasil generalisasi dari fakta-fakta yang dikumpulkan melalui dokumen-dokumen sejarah. Kemudian Setelah itu ditampilkan fakta-fakta mengenai konflik agama di akhir era Orde Baru. Selanjutnya diuraikan mengenai kondisi hubungan antaragama di awal Reformasi, secara khusus dalam kaitan dengan dampak politik identitas Orde Baru.

Dilihat dari jenisnya, penelitian ini termasuk dalam penelitian kepustakaan (library research) yang berusaha mengumpulkan buku-buku literatur sebagai data-data primer dan sekunder, dan kemudian mempelajarinya berdasarkan pengumpulan data berupa dokumentasi, baik melalui buku-buku penelitian sebelumnya maupun surat kabar, jurnal dan sebagainya. Sedangkan sifat dari penelitian ini termasuk penelitian deskriptif analisis yaitu prosedur pemecahan masalah yang diselidiki dengan membuat deskripsi, gambaran atau lukisan secara sistematis, faktual dan akurat mengenai fakta-fakta, sifat-sifat serta hubungan antarfenomena yang diselidiki. ${ }^{1}$

\section{Masa Orde Baru}

Setidaknya ada tiga tahapan peristiwa besar yang mengawali pemerintahan Orde Baru yang dipimpin oleh Soeharto, dan jatuhnya pemerintahan Orde Lama yang dipimpin oleh Soekarno pada masa itu. Ketiga tahap peristiwa itu dimulai dengan timbulnya suatu peristiwa yang kemudian disebut Gerakan 30 September 1965 antara Angkatan

1 Moh. Nazir, Metode Penelitian (Jakarta: Ghalia Indonesia, 1988), 63. 
Darat (AD) dengan Soekarno yang didukung oleh PKI (Partai Komunis Indonesia) ${ }^{2}$ dan Panglima Angkatan Udara, Omar Dhani, yang puncak pemberontakannya adalah dibunuhnya enam jenderal dan seorang letnan. Hefner dalam bukunya menjelaskan mengenai peristiwa tersebut bahwa tiga di antaranya ditembak mati di rumah mereka karena melawan, sedangkan yang lainnya dibawa ke markas Angkatan Udara (AU) di Halim, Jakarta Timur. Lalu di hadapan para kader PKI dan para perwira militer yang ikut memberontak, mereka dieksekusi dan mayat mereka (termasuk tiga jenderal yang telah dibunuh sebelumnya) dibuang ke sebuah lubang sumur (kelak dikenal dengan nama Lubang Buaya). Jenderal Abdul Haris Nasution, perwira paling senior lolos dari upaya penculikan tersebut, tetapi naas putrinya, Irma Suryani Nasution, tertembak dalam serangan itu ${ }^{3}$. Para pemberontak merasa keadaan sudah dipegang oleh mereka dengan berdalih bahwa tindakan mereka itu

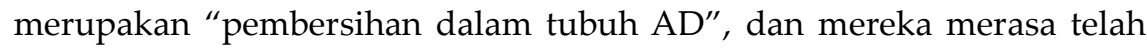
menguasai TNI (Tentara Nasional Indonesia). Tetapi ternyata mereka keliru sebab Panglima Kostrad Mayjen Soeharto yang mereka kira akan mendukung gerakan itu, ternyata menanggapinya secara terbalik. Sebab Soeharto menganggap bahwa langkah para pemberontak tersebut merupakan kekeliruan yang sangat besar. Soeharto bahkan melawan para pemberontak tersebut, hingga pada suatu tahap Soeharto melakukan rencananya untuk menyerang Soekarno melalui propaganda untuk membatasi kekuasaan Soekarno saat itu.

Dan yang kedua, melalui TNI yang memobilisasi ratusan ribu relawan sipil di berbagai daerah untuk membantu mendata, menahan dan bahkan mengeksekusi kader-kader PKI dan membantai para anggota

2 Untuk lebih mendalami peristiwa ini, lihat: Hefner, Civil Islam: Islam dan Demokrasi di Indonesia, terj. Ahmad Baso (Yogyakarta: Lkis, 2001), 115. Pembahasan dalam bagian ini hanya ringkasan dari tulisan Hefner.

3 Hefner, Civil Islam: Islam dan Demokrasi di Indonesia, terj. Ahmad Baso (Yogyakarta: Lkis, 2001), 117. 
PKI, khususnya di daerah-daerah yang memiliki basis pendukung PKI ${ }^{4}$. Pada tahapan yang kedua seperti yang diuraikan Benyamin Fleming Intan, dalam bukunya yang menjelaskan bagaimana runtuhnya pemerintahan Orde Lama ke tangan Orde Baru tidaklah semudah membalikkan telapak tangan, beberapa upaya seperti yang dijelaskan menyatakan bahwa adanya peran dari pihak tentara yaitu AD yang pada saat itu dipimpin oleh Jenderal Soeharto menggunakan rakyat yang pada saat itu dimotori oleh para mahasiswa yang tergabung dalam Angkatan 66 (generasi 1966) dari berbagai elemen pemuda, baik Muslim, Protestan dan Katolik yang tergabung dalam KAMI (Kesatuan Aksi Mahasiswa Indonesia) dan KAPPI (Kesatuan Aksi Pemuda dan Pelajar Indonesia) meminta Soekarno untuk memenuhi tiga tuntutan mereka; yaitu (i) membubarkan PKI, (ii) membersihkan kabinet dari semua elemen komunis, dan (iii) menurunkan harga bahan-bahan pokok, guna memerbaiki kehidupan ekonomi ${ }^{5}$. Namun seperti yang dijelaskan oleh Intan bahwa Soekarno yang saat itu menjabat sebagai presiden dan mendukung PKI tidak dapat memenuhi tuntutan mereka. Intan menjelaskan "Sukarno, however, was not able to fulfill their demands, and therefore he fell from power" yang akhirnya menurut Boland, pada bulan Maret 1966 melalui desakan dan kondisi yang dialami oleh Soekarno untuk memulihkan keadaan dan stabilitas negara maka Soekarno melalui surat kuasa yang dituliskannya memerintahkan Jenderal Soeharto untuk

\footnotetext{
4 Hefner, Civil, 122-124. Hefner menjelaskan bahwa tingkat pembantaian yang besar berakhir pada akhir Desember 1965, dan terus berlanjut dibeberapa tempat hingga pertengahan 1966. Dan juga eksekusi-eksekusi juga terulang di Jawa Tengah dan Jawa Timur pada tahun 1968 dan 1969, dengan jumlah korban sekitar 500 ribu orang dibunuh. 5 Benyamin Fleming Intan, "Public Religion" and the Pancasila-Based State of Indonesia: An Ethical and Sociological Analysis (New York: Peter Lang, 2006), 50. Buku ini merupakan Disertasi yang diselesaikannya di Boston College pada tahun 2004. Dalam disertasinya ini ia memberikan sumbangsih mengenai gagasan menjadikan Pancasila sebagai "agama publik" dan dasar negara di Indonesia yang multikultural ini. Lihat juga, B.J. Boland, Pergumulan Islam di Indonesia 1945-1972, terj. Saafroedin Bahar (Jakarta: PT Grafiti Pers, 1985), 148, Boland menjelaskan bahwa dalam gerakan mahasiswa, yaitu KAMI (Kesatuan Aksi Mahasiswa Indonesia) yang memiliki peran dalam melakukan aksi tersebut terdapat juga HMI (Himpunan Mahasiswa Islam) yang amat kuat serta memiliki hubungan yang tidak resmi dengan Masyumi dan organisasi Muslim modern lainnya.
} 
mengambil segala tindakan yang perlu untuk keselamatan dan stabilitas negara serta pemerintah dan melindungi Soekarno sebagai "Presiden, Panglima Tertinggi, Pemimpin Besar Revolusi, dan Mandataris Majelis Permusyawaratan Rakya". ${ }^{6}$ Namun ternyata menurut Hefner surat yang disebut sebagai Surat Perintah Sebelas Maret (Super Semar) tersebut yang diberikan oleh Soekarno kepada Soeharto yang diduga moderat di kalangan $\mathrm{AD}$ ternyata digunakan untuk melegitimasi kekuasaannya untuk melakukan tindakan-tindakan yang akhirnya menyerang dan melumpuhkan Soekarno.7 Surat tersebut seperti yang dijelaskan oleh Kansil dan Julianto dalam bukunya bahwa berdasarkan Surat Perintah 11 Maret 1966 itulah Jenderal Suharto (pemegang Super Semar) atas nama Presiden/Panglima Tertinggi ABRI pada tanggal 12 Maret 1966 mengeluarkan Keputusan Presiden No.1/3/1966 yang isinya menyatakan pembubaran PKI termasuk semua bagian organisasinya dari tingkat pusat sampai daerah. Dan keputusan ini diperkuat oleh Ketetapan MPRS No. XXV/MPRS/1966 yang isinya memperkuat keputusan Presiden tersebut yaitu membubarkan PKI dan menyatakannya sebagai partai dan paham yang dilarang8 ${ }^{8}$ hingga pada puncaknya pada tahap yang ketiga, di mana seperti yang dijelaskan oleh Hefner bahwa pada pertengahan Maret 1967, gerakan anti-Soekarno mencapai tahap akhir yang dramatis. Lebih jauh ia menjelaskan mengenai peristiwa tersebut bahwa dengan kekuatan sekitar 80 ribu personil AD yang menguasai ibu kota, MPR yang bertugas memilih presiden dan merumuskan GBHN, memecat Soekarno dari kursi kekuasaan dan mengangkat Soeharto sebagai penjabat presiden, dan yang setahun kemudian diangkat menjadi

\footnotetext{
6 Boland, Pergumulan, 149.

7 Hefner, Civil, 132.

8 C.S.T. Kansil dan Julianto, Sejarah Perjuangan Pergerakan Kebangsaan Indonesia (Jakarta: Erlangga, 1982), 88. Kansil dan Julianto menjelaskan bahwa Ketetapan MPRS No. XXV/MPRS/1966 itu dinyatakan bahwa setiap kegiatan di Indonesia untuk menyebarkan atau mengembangkan paham atau ajaran Komunisme/Marxisme-Leninisme dalam segala bentuknya dan manifestasinya, dan penggunaan segala aparatur serta media bagi penyebaran atau pengembangan paham atau ajaran tersebut, dilarang.
} 
presiden sepenuhnya. Soeharto kemudian menamai pemerintahannya dengan istilah: Orde Baru.

\section{Politik Identitas pada Masa Pemerintahan Orde Baru}

Pada pemerintahan Orde Baru yang dipimpin oleh Soeharto itu, kalangan Islam yang ikut mendukung penumpasan PKI, merasa bahwa keinginan mereka akan terwujud karena "jasa-jasa" mereka cukup besar dalam peristiwa penumpasan PKI itu, sehingga mereka menaruh harapan yang besar bagi pemerintahan yang baru tersebut, hal ini seperti yang dijelaskan oleh Hefner, ia mengatakan bahwa:

Bagi sebagian dari mereka, pemerintahan yang baru ini tampak akan menawarkan kemungkinan satu "orde yang baru", yang bakal mengembalikan Islam ke posisi yang sah dalam kehidupan publik. ${ }^{9}$

Hal yang sama juga dijelaskan oleh Boland, bahwa pada periode ini kalangan Islam politik sangat mengharapkan sekali cita-cita mereka yang semula dapat terwujud di dalam pemerintahan yang baru tersebut. ${ }^{10}$ Namun keinginan kalangan politik Islam itu kandas, dan mereka kembali mendapatkan kekecewaan yang mendalam, karena ternyata harapan dan keinginan mereka tidak sejalan dengan pemerintahan yang baru tersebut. Richard Daulay di dalam tulisannya menjelaskan mengenai sikap pemerintahan Orde Baru terhadap kalangan politik Islam sebagai berikut;

Selama pemerintahan Orde Baru, tidak ada peluang bagi gerakan Islam politik untuk memperjuangkan cita-cita mendirikan negara Islam melalui jalur politik. Bahkan semua lembaga keagamaan, terutama Islam sebagai agama terbesar, dijadikan sebagai alat legitimasi kebijakan-kebijakan pemerintah. Soeharto tidak memusuhi Islam sebagai agama, karena ia sendiri dan keluarganya beragama Islam, tetapi memusuhi Islam politik

\footnotetext{
9 Hefner, Civil, 114.

10 Lihat Boland, Pergumulan, 158.
} 
yang berniat mendirikan negara Islam. ${ }^{11}$

Hefner mengatakan, bahwa sejak awal sudah muncul tanda-tanda yang menunjukkan sikap ambivalensi sebagian penguasa Orde Baru terhadap organisasi politik umat Islam, lebih jauh ia menjelaskan bahwa pemerintahan lebih memilih langkah politik yang sifatnya menggabungkan antara kontrol yang keras terhadap Islam politik dan dukungan penuh terhadap Islam spiritual ${ }^{12}$ dengan strategi membentuk agama sebagai landasan moralitas publik dan sebagai tameng untuk menghadapi pengaruh liberalisme Barat dan juga sebagai penangkal terhadap komunisme seperti yang dijelaskan oleh Hefner, yang bertujuan agar agenda politik dari kalangan Islam politik tidak berjalan dan mengganggu agenda-agenda politik dari pemerintahan yang sedang berjalan tersebut.

Dapat dikatakan bahwa di awal pemerintahan yang baru itu, pemerintah tersebut sangat menekan gerakan Islam politik yang ingin menyalurkan keinginan mereka melalui pemerintahan yang baru berjalan. Yang berarti keinginan dan harapan kalangan politik Islam yang ingin mendirikan negara Islam melalui jalur politik di pemerintahan yang baru tersebut mendapat tantangan yang besar, dan yang berarti harapan tersebut harus disingkirkan dari pikiran mereka, karena pemerintahan yang sedang berjalan itu, ternyata memiliki agendaagenda politik tersendiri guna menjalankan pemerintahannya. Dan yang akhirnya juga membawa kepahitan bagi kalangan Islam politik memasuki pemerintahan Orde Baru yang dipimpin oleh Soeharto dengan segala agenda-agenda politiknya bagi kepentingan yang lebih luas, yaitu terjaganya ketenteraman di seluruh wilayah kesatuan

11 Richard M. Daulay, Agama \& Politik di Indonesia: Umat Kristen di Tengah Kebangkitan Islam (Jakarta: BPK Gunung Mulia, 2016), 85. Buku ini merupakan disertasi yang dipertahankannya di Sekolah Pascasarjana Universitas Gadjah Mada UGM), Program Studi Agama dan Lintas Budaya, pada tanggal 15 Desember 2014, dengan pembahasan mengenai sikap politik umat Kristen (Protestan) terhadap kebangkitan "Islam Politik" di Indonesia pada Era Reformasi.

12 Hefner, Civil, 114. 
Indonesia. Oleh karena itu, salah satu langkah yang dilakukan oleh Soeharto adalah mencari dukungan dari ABRI (Angkatan Bersenjata Republik Indonesia) dengan cara memerkuat dwifungsi ABRI ${ }^{13}$ pada masa itu. Daulay menjelaskan bahwa pihak ABRI diposisikan sebagai kekuatan pertahanan dan keamanan (hankam) dan sekaligus sebagai kekuatan politik ${ }^{14}$. Oleh karena itu tidak heran jika di masa-masa awal pemerintahannya seperti yang dijelaskan oleh Daulay bahwa mayoritas jabatan pemerintahan, mulai dari menteri, gubernur, bupati/walikota sampai kepala desa (lurah) dipegang oleh personel ABRI, baik yang sudah pensiun maupun yang masih aktif semuanya dikaryakan. Dengan begitu Soeharto mendapatkan dukungan yang penuh dari ABRI sebagai pilar utama perpolitikan di Indonesia pada masa itu. Dari sini dapat dilihat bagaimana dukungan ABRI kepada Soeharto semakin besar dalam pemerintahannya.

Selanjutnya ialah bagaimana Soeharto menekan dan menghilangkan gerakan-gerakan yang dianggapnya sebagai "musuh" terhadap kemajuan dan ketenteraman bangsa ini, yaitu, pertama, dengan menekan gerakan Islam politik yang ingin kembali menghidupkan Partai Masyumi sebagai roda perpolitikan dari Islam politik yang ingin memerjuangankan keinginan mereka, dan yang kedua menghilangkan gerakan atau ideologi komunis di Indonesia dengan cara menumpas dan membubarkan PKI seperti yang telah dijelaskan di atas. Dan menurut Darmaputra, bahwa fokus dari pemerintahan tersebut "kembali kepada jiwa dan makna asli dari Pancasila, dan melaksanakan UUD 1945 secara konsekuen"15, dan yang berarti kalangan Islam politik kembali mengalami tantangan yang begitu besar untuk mewujudkan keinginan dan harapan mereka yang begitu besar.

\footnotetext{
13 Untuk dapat memahami konsep Dwifungsi ABRI dapat dilihat dalam tulisan, Bilveer Singh, Dwifungsi ABRI: Asal-usul Aktualisasi dan Implikasinya bagi Stabilitas dan Pembangunan, terj. Robert Hariono Imam (Jakarta: PT Gramedia, 1996), 44.

14 Daulay, Agama, 115.

15 Eka Darmaputera, Pancasila: Identitas dan Modernitas, Tinjauan Etis dan Budaya (Jakarta: BPK Gunung Mulia, 1993), 114.
} 
Setelah berkuasa selama 20 tahun pemerintahan Orde Baru yang dipimpin oleh Soeharto akhirnya mengubah sikapnya terhadap kalangan Islam politik seperti yang dijelaskan oleh Kirchberger dalam tulisannya:

Pada pertengahan tahun 1990-an rezim ORBA-Suharto yang merasa legitimasi kekuasaannya semakin tergerus, mulai memperlihatkan perubahan sikap mendasar yaitu memberi dukungan pada kekuatan Islam Politik. Kekuatan Islam Politik dirangkul untuk memperkuat posisinya. ${ }^{16}$

Demikian juga Daulay menjelaskan bahwa perubahan di saat usia Soeharto sudah semakin tua (69 tahun), dan ketika kaum intelektual Islam sudah sangat kuat, ia mengubah strategi politik konfrontatifnya terhadap Islam, yang berlangsung sejak awal Orde Baru sampai pertengahan tahun 1980-an menjadi akomodatif ${ }^{17}$ dalam merangkul dan mendukung kalangan Islam politik.

\section{Masa Era Reformasi}

Di awal era Reformasi ${ }^{18}$ dan berakhirnya Orde Baru terdapat begitu banyak peristiwa buruk yang sampai menelan begitu banyak korban di kalangan masyarakat. Hal ini seperti yang digambarkan oleh Crouch, dalam tulisannya:

The collapse of the New Order lifted the lid on simmering communal tensions in many regions of Indonesia. During the New Order violent conflicts between local ethnic and religious communities had broken out from time to time, but from 1998 to the early 2000s the extent and intensity of violence increased sharply. ${ }^{19}$

\footnotetext{
16 Georg Kirchberger, "Problematik Kekerasan dalam Pandangan Agama Kristiani" dalam Jurnal Ledalero Vol. 17 no. 1 (Juni 2018).

17 Richard M. Daulay, Kristenisasi \& Islamisasi: Umat Kristen dan Kebangkitan Islam Politik Pada Era Reformasi di Indonesia (Jakarta: BPK Gunung Mulia, 2014), 3.

18 Lihat Daulay, Agama, 152. Mengenai lahirnya era Reformasi.

19 Harold Crouch, Political Reform in Indonesia After Soeharto (Singapore: Institute of Southeast Asian Studies, 2010), 242.
} 
Senada dengan itu, mengenai ketegangan yang terjadi di bangsa ini, di dalam bukunya Myengkyo Seo juga menjelaskan bahwa:

"The Asian financial crisis in 1997 and the fall of Suharto (1921-2008), the second President of Indonesia, in May 1998 brought about unprecedented levels of violence and criminality, stemming notably from Indonesia's religious geography." 20

Beberapa peristiwa besar seperti masalah krisis ekonomi yang menjadi awal terjadinya berbagai benturan di akhir era Orde Baru dan awal Reformasi dapat dilihat bahwa walaupun awalnya tidak memiliki hubungan langsung dengan konflik bernuansa agama seperti kerusuhan Mei 1998 yang merupakan pintu bagi lahirnya era Reformasi dengan kejatuhan Soeharto. Era Reformasi juga menghapus banyak hal yang berkaitan dengan pemerintahan Orde Baru, termasuk mengamandemen UUD 1945 yang berkaitan dengan masa jabatan presiden. Namun akhirnya merembet ke masalah hubungan antaragama, yaitu benturan antara atau konflik umat Kristen dengan Islam yang dimulai dengan berbagai peristiwa konflik di bangsa ini yang akhirnya menelan begitu banyak korban, khususnya umat Kristen di berbagai daerah. Beberapa konflik seperti yang dicatat oleh Aritonang di dalam bukunya di antaranya ${ }^{21}$ :

- Kerusuhan di Jalan Ketapang Jakarta dan di Kupang, November 1998

- Kerusuhan di Poso pada tahun 1998-2002

- Kerusuhan di Ambon, tahun 1999-2002

- Ledakan bom di Malam Natal tahun 2000 di beberapa daerah, seperti di Jakarta, Sukabumi, Mojokerto, Bandung, Pekanbaru, Batam, dan Mataram-Lombok.

Peristiwa-peristiwa tersebut dapat dikatakan memiliki hubungan langsung dengan benturan antara Kristen dan Islam yang sangat

\footnotetext{
20 Myengkyo Seo, State Management of Religion in Indonesia (Abingdon: Routledge, 2013), 4.

21 Jan S. Aritonang, Sejarah Perjumpaan Kristen dan Islam di Indonesia (Jakarta: BPK Gunung Mulia, 2004), 533-64.
} 
merugikan, bukan hanya kerugian secara ekonomi dan dari segi infrastruktur namun juga menelan begitu banyak korban jiwa. Selain konflik-konflik yang sangat merugikan, muncul juga ketegangan berikutnya dengan lahirnya beberapa isu yang sangat krusial yang berkaitan dengan proses islamisasi oleh kalangan Islam politik yang memanfaatkan era Reformasi yang demokratis ini, dengan usaha dan cara yang untuk mewujudkan keinginan mereka, di antaranya:

- munculnya kembali keinginan untuk memperjuangkan kembalinya "tujuh kata" ke dalam Piagam Jakarta.

- undang-undang Syariat Islam di berbagai daerah.

Namun usaha mereka (Islam politik) untuk memasukkan kembali “tujuh kata" tersebut pada tahun 1999-2004 melalui sidang tahunan MPR gagal. Namun bukan berarti keinginan mereka untuk mengislamkan negara ini berhenti. Keinginan dan perjuangan mereka diteruskan melalui DPR melalui diterapkannya perda-perda syariah di berbagai daerah. Dan usaha penerapan perda-perda syariah ini dinilai berhasil, seperti yang dijelaskan oleh Daulay, bahwa dalam kurun waktu lima belas tahun terakhir (1998-2013) perjuangan mereka cukup berhasil, walaupun mereka gagal melakukan perubahan pada pasal 29 UUD 1945 untuk memasukkan prinsip "syariat Islam".22 Sementara dalam tulisannya Victor Silaen menyebutkan beberapa daerah yang telah menerapkan syariat Islam:

Tercatat antara lain di Indramayu dengan Perda Nomor 7 Tahun 1999, Sumatera Barat dengan Perda Nomor 11 Tahun 2001, ditambah lagi dengan Instruksi Wali Kota Padang pada 7 Maret 2005. Bengkulu memberlakukan Perda Nomor 24 Tahun 2000 serta Instruksi Nomor 3 Tahun 2004. Solok memberlakukan Perda Nomor 10 Tahun 2001, serta Perda Nomor 6 Tahun 2002. Enrekang dengan Perda Nomor 6 Tahun 2005, Bulukumba dengan Perda Nomor 4 Tahun 2003, Maros dengan Perda Nomor 15 Tahun 2005. Perda dengan substansi yang hampir sama

22 Daulay, Agama, 174. 
telah dibuat dan berlaku di Nusa Tenggara Barat, Takalar, Sinjai, Gowa, Banten, Tasikmalaya, dan Cianjur." 23

Dengan demikian setidaknya usaha tersebut mendapat angin segar dalam proses islamisasi melalui peraturan-peraturan daerah (perda syariah) yang disahkan melalui DPR dan DPRD di berbagai daerah. Pemberlakuan perda-perda syariah ini tentunya menimbulkan ketegangan dan kerugian bagi masyarakat minoritas. Sebab dengan adanya berbagai perda yang mengarah hanya kepada satu agama yaitu Islam, membuat masyarakat pemeluk agama lain merasa terpinggirkan, dan bahkan menyulitkan agama lain untuk melakukan aktivitas keagamaannya.

Dalam hal ini dapat dikatakan bahwa umat Kristen--walaupun terdapat juga agama-agama yang lainnya--mendapatkan dampak yang sangat merugikan dari setiap kebijakan yang diterapkan oleh pemerintahan yang tidak adil dalam memberikan kebijakan-kebijakan yang dibuat karena lebih memilih mendengarkan suara mayoritas melalui setiap keputusan perundang-undangan yang dikeluarkan oleh pemerintah, baik yang ada di daerah maupun di pusat, malah yang akhirnya juga menimbulkan ketegangan di antara kedua pemeluk agama ini. Ketegangan antara lain, mulai dari masalah pembangunan rumah ibadah dengan dikeluarkannya SKB No.1/1969, dan kemudian revisi pada tahun 2006, yang kemudian menjadi alat legitimasi bagi sebagian ormas untuk melakukan tekanan dan penutupan terhadap gerejagereja ${ }^{24}$, kemudian mengenai UU Perkawinan tahun 1973 dan juga munculnya berbagai peraturan yang bernuansa syariah di berbagai daerah di Nusantara ini. Justru kebijakan-kebijakan tersebut membuat ketegangan di antara penganut kedua agama itu semakin meningkat dan diwarnai dengan berbagai konflik hingga sampai saat ini dan terus

\footnotetext{
23 Victor Silaen, "Tinjauan Kritis atas Perda-Perda Bermasalah" dalam Jurnal: Sociae Poliyes Vol. 5 no. 25 (Jakarta: Fakultas Ilmu Sosial dan Ilmu Politik Universitas Kristen Indonesia, 2007): 15.

24 Lihat Seo, State, 70.
} 
meningkat. Perda-perda yang bersifat diskriminasi ini sebetulnya menjadi sebuah permasalahan di bangsa ini, dan akan semakin memburuk dan bias membawa bangsa ini ke jurang perpecahan (disintegrasi).

\section{Dampak Politik Identitas Era Orde Baru}

Dampak politik identitas yang dilakukan pada masa pemerintahan Orde Baru yang digunakan sebagai alat politik untuk dapat menahan pergerakan kaum Islam politik sebenarnya hanya seperti sebuah keran yang ditutup sementara untuk menghentikan gerakan mereka yang dapat mengganggu setiap program dari pemerintahan tersebut. Oleh karena itu ketika pemerintahan Orde Baru yang sudah semakin lemah dan hampir kehilangan kekuatannya karena tidak lagi didukung oleh kalangan militer, maka dalam situasi tersebutlah keran yang ditutup itu dibuka kembali sehingga pergerakan Islam politik di awal era Reformasi dan di akhir masa Orde Baru seperti mendapat angin segar bagi pergerakan mereka yang sempat terhenti itu. Hal ini dapat dilihat ketika kekuatan Islam politik makin kuat dan akhirnya duduk dalam pemerintahan dan berusahan mewujudkan keinginan mereka. Walaupun konstitusi Undang Undang Dasar 1945 tidak dapat diubah namun setidaknya melalui beberapa perda-perda syariat yang telah diterapkan di berbagai daerah telah berhasil dijalankan dan yang akhirnya menimbulkan ketegangan yang sebenarnya ditakutkan oleh pemerintahan-pemerintahan yang sebelumnya. Ketegangan-ketegangan tersebut bukan hanya terjadi secara politik melainkan juga dalam bentuk fisik yang akhirnya menimbulkan konflik antarsaudara setanah air yang menelan korban dengan jumlah yang sangat banyak di berbagai daerah. Dan selain konflik yang terjadi timbul juga gerakan-gerakan garis keras untuk memropagandakan keinginan mereka untuk mendirikan negara Islam dengan menggantikan ideologi Pancasila. Namun yang perlu dicatat dan diingatkan dalam tulisan ini bahwa pergerakan tersebut walaupun sempat menimbulkan ketegangan yang besar dan sangat 
merugikan hal itu hanya dilakukan oleh sebagian elemen masyarakat yang tergabung dalam pergerakan radikal. Jumlah mereka sebenarnya kecil jika dibandingkan mayoritas masyarakat dari semua elemen yang ingin mempertahankan kesatuan negara ini.

Aritonang menjelaskan, hubungan Kristen dan Islam semakin memburuk memasuki Era Reformasi:

Setelah terjadinya pergantian rezim dari kekuasaan Orde Baru ke arah Era Reformasi yang begitu pahit karena mengakibatkan jatuhnya sejumlah korban karena begitu banyaknya kerusuhan pada tahun-tahun terakhir di masa akhir kekuasaan rezim Orde Baru yang dianggap sebagai tumbal, toh diharapkan membawa hubungan yang lebih baik di antara umat Kristen dan Islam,...ternyata harapan itu tidak menjadi kenyataan, paling tidak sampai tahun 2002, bahkan sebaliknya cenderung memburuk. ${ }^{25}$

Lebih lanjut ia menjelaskan bahwa walaupun dalam masa-masa peristiwa yang mewarnai jatuhnya rezim Orde Baru memasuki Era Reformasi tidak memiliki hubungan langsung dengan hubungan kedua agama ini namun peristiwa tersebut justru memiliki dampak buruk yang besar bagi kedua agama, hingga menjelang awal pemerintahan di era Reformasi. Senada dengan itu, dalam tulisan "50 Tahun Persekutuan Gereja-gereja di Indonesia (PGI)" yang menyoroti latar belakang masalah yang terjadi di masa-masa berakhirnya pemerintahan Orde Baru menuju era Reformasi yang menimbulkan gejolak, dia menuliskan bahwa:

Dalam dasawarsa ini, terutama pada parohan kedua, volume dan frekuensi gejolak dan keresahan semakin besar dan gencar, dan sangat sering menjadikan gereja (bersama dengan WNI keturunan Cina) sebagai sasarannya. Semua itu berpuncak pada tumbangnya rezim Orde Baru melalui gerakan dan proses Reformasi yang menggelinding sejak awal 1998, setelah didahului oleh serangkaian krisis yang bersifat multidimensional sejak akhir 1997. ${ }^{26}$

\footnotetext{
25 Aritonang, Sejarah, 513.

26 Jan S. Aritonang (peny.), 50 Tahun PGI Gereja di Abad 21: Konsiliasi untuk Keadilan, Perdamaian dan Keutuhan Ciptaan (Jakarta: Badan Penelitian dan Pengembangan Persekutuan Gereja-gereja di Indonesia, 2000), 125.
} 
Hubungan yang tidak baik di antara keduanya justru semakin meningkat di masa itu yang akhirnya menimbulkan konflik yang kian terulang di masa-masa sebelumnya dengan dampak yang begitu besar mengakibatkan ketidakharmonisan, ancaman disintegrasi, dan ketegangan yang begitu mencekam hingga mengakibatkan terjadinya berbagai macam peristiwa buruk yang terjadi di berbagai daerah seperti yang diuliskan oleh Benyamin Fleming Intan:

Never before in the Indonesian history has this "old problem" of the place and role of religion been so severe as it is at present. This growing problem has become not only intense and profound, but it has also caused so much violence as to bring the whole nation to the brink of disintegration..$^{27}$

Masalah lama yang terjadi di masa penjajahan antara kedua agama ini kembali terjadi lagi di masa yang sudah tidak lagi berhubungan dengan kolonial atau penjajahan menimbulkan ketegangan yang begitu besar dan mengarah kepada konflik yang menelan begitu banyak korban dari kedua belah pihak. Ketegangan yang terjadi di antara kedua kelompok umat tersebut menimbulkan suatu tantangan yang besar dalam kehidupan beragama pada bangsa ini yang sejak dahulu kala sudah hidup rukun sebagai masyarakat yang multikultural. Tantangan tersebut menjadi sebuah dorongan bagi setiap agama di Indonesia untuk segera merespon dalam menata kembali kehidupan beragama yang lebih harmonis dan toleran dalam suatu bangsa yang hidup dalam keberagaman ini.

\footnotetext{
27 Intan, "Public Religion", 1. Beberapa data dan keterangan mengenai peristiwa yang menelan korban begitu banyak juga disajikan di awal pembahasannya. Setidaknya ada beberapa peristiwa yang terjadi, mulai dari tahun 1995-1997, yang terjadi di Jawa, dimana beberapa gedung gereja dirusak, dan pada tahun 1998 menyebabkan 1.198 orang terbunuh dan peristiwa yang mengakibatkan trauma yang mendalam bagi salah satu etnis, dan pada tahun 1999-2002 di Maluku antar umat beragama yaitu Kristen dan Islam yang menelan korban 10.000 orang terbunuh. Lihat juga, Robert W. Hefner, Civil Islam: Islam dan Demokrasi di Indonesia, terj. Ahmad Baso (Yogyakarta: Lkis, 2001), 21. Hefner menjelaskan bahwa dalam lingkaran kekerasan anti-Kristen yang belum pernah terlihat dalam sejarah Indonesia, kira-kira 400 gereja, kebanyakan dimiliki jemaat Cina, dirusak atau dimusnahkan antara tahun 1997-1998.
} 


\section{Kesimpulan}

Politik identitas yang dimainkan pemerintahan Orde Baru untuk melatenkan kekuasaannya, ternyata tidak berhasil menyelamatkan kekuasaan Orde Baru. Terbukti, konflik agama dalam skala yang besar terjadi pada akhir era Orde Baru, politik agama yang dimainkan Orde Baru tersebut ternyata berdampak luas hingga era reformasi. Konflik dengan skala besar yang mengancam integrasi bangsa terus berlanjut pada awal era Reformasi. Pemerintah sepatutnya mewaspadai usahausaha politisasi agama, sebab sikap diam pemerintah akan berdampak pada terjadinya disintegrasi bangsa. Politik identitas Orde Baru harus dibayar mahal dengan konflik-konflik berkepanjangan di awal era Reformasi, dan hal itu mestinya menjadi alarm bagi pemerintah dan semua elemen bangsa supaya tidak mencoba-coba memainkan politik identitas. 